\title{
Model Bantu Deteksi Masker Sebagai Pencegahan Virus Covid- 19 Pada New Normal Bagi Penyandang Tunanetra
}

\author{
Krisna Dwiki Aldi', Dody Widjanarko ${ }^{2}$, Binti Muniroh ${ }^{3}$, Sulfan Bagus Setyawan ${ }^{4}$ \\ 1,2,3,4 Teknik Komputer Kontrol, Politeknik Negeri Madiun
}

\begin{tabular}{l}
\hline \hline Article Info \\
\hline Article history: \\
Received Jun $12^{\text {th }}, 2021$ \\
Revised Aug $20^{\text {th }}, 2021$ \\
Accepted Aug $31^{\text {th }}, 2021$
\end{tabular}

\section{Keyword:}

Covid-19

Penyandang Tunanetra

Objek Deteksi

CNN

Tensorflow

\begin{abstract}
Wabah pneumonia baru-baru ini yang disebabkan oleh coronavirus

(COVID-19) menunjukkan risiko luar biasa terhadap kesehatan masyarakat dunia. Virus Covid-19 juga berdampak pada penyandangtunanetra. Namun alat yang mendukung tunanetra dalam menghadapi virus Covid-19 masih terbatas. Penelitian ini bertujuan untuk membantu penyandang tunanetra agar dapat mengetahui orang di sekitarnya menerapkan protokol kesehatan dengan memakai masker dan menjaga jarak, serta pengasuh dapat melakukan pengawasan lokasi dan kondisi penyandang tunanetra melalui smartphone. Metode deteksi yang digunakan pada penelitian ini menggunakan Convolutional Neural Network (CNN). Dengan menggunakan Tensorflow sebagai framework deep learning yang mampu mengenalidan mengklasifikasi suatu objek. Langkah pertama adalah mengumpulkan dataset jenis-jenis masker yang sering digunakan masyarakat, dilanjutkan representasi dataset sebelum dimodelkan ke dalam perhitungan matematis yang nantinya akan diolah menggunakan metode CNN dengan arsitektur MobileNet-V2. Hasil pembelajaran mesin deteksi masker mendapatkan akurasi sebesar $98 \%$. Sistem deteksi masker dan estimasi jarak akan diimplementasikan pada Raspberry Pi dan mendapatkan FPS sebesar 0,33. Hasil klasifikasi deteksi masker dan estimasi jarak akan diterimapengguna melalui earphone. Sistem pengawasan pada alat ini yaitu pengasuh dapat melakukan monitoring secara real time suhu badan, keadaan dan lokasi keberadaan penyandang tunanetra melalui aplikasi smartphone. Pada aplikasi tersebut dilengkapi dengan API Google Maps sehingga dapat menampilkan lokasi penyandang tunanetra.
\end{abstract}

Copyright (C) 2021 STMIK Triguna Dharma. All rights reserved.

\footnotetext{
Corresponding Author: *First Author

Nama : Krisna Dwiki Aldi

Program Studi : Teknik Komputer Kontrol

Politeknik Negeri Madiun

Email : krisnaaldi123@gmail.com
}

\section{PENDAHULUAN}

Virus baru yang disebut oleh 2019-nCoV diumumkan oleh Organisasi Kesehatan Dunia (WHO) pada Januari 2020 [15]. Pandemi Covid-19 (Coronavirus) dapat menyebabkan gangguan pernapasan ringan hingga berat bagi manusia, saat ini jumlah kasus penyebarannya terus meningkat. Segala bentuk usaha pencegahan penyebaran virus Covid-19 terus dilakukan oleh pemerintah terutama dengan membentuk satgas penanganan Covid-19 [9]. Gejala Covid-19 antar individu dapat berbeda, namun gejala umum seperti demam,batuk kering, dan kelelahan diidentifikasi pada sebagian besar pasien. Selain itu, orang yang terinfeksi mungkin juga merasakan sakit flu, radang tenggorokan, hidung tersumbat dan menghilangnya indra penciuman. Namun 
pada beberapa kasus pembawa virus mungkin tidak merasakan gejala apa pun meskipun terinfeksi oleh virus Covid-19. Pada kasus yang cukup berat dapat menyebabkan sindrom pernapasan akut, pneumonia, bahkan kematian. Masa inkubasi virus covid-19 sekitar 7 sampai 14 hari. Covid-19 menyebar melalui udara dan kontak langsung dengan penderita. Meskipun, pasien yang terinfeksi yang bertahan mencapai $80 \%$, tetapi sangat berbahaya bagi orang lanjut usia atau pasien dengan penyakit serius yang memiliki tingkat lebih rendah untuk bertahan hidup [12]. Munculnya wabah Covid-19 mendorong pentingnya menjalankan protokol kesehatan dalam mencegah penyebaran virus tersebut. Masih banyaknya masyarakat yang belum menerapkan protokol kesehatan dalam pencegahan virus covid-19 dengan baik menjadi alasan pemerintah untuk melakukan peningkatan pengetahuan warga menerapkan protokol kesehatan dengan melakukan 3M, yaitu memakai masker, menjaga jarak dan mencuci tangan [8].

Risiko komplikasi dari virus Covid-19 lebih tinggi pada beberapa populasi rentan, terutama lanjut usia, individu yang berkebutuhan khusus, atau yang memiliki beberapa kondisi kronis .Virus Covid-19 juga berdampak pada penyandang tunanetra. Tetapi penyandang tunanetra tidak dapat mengetahui yang tidak menggunakan masker dan jarak terhadap orang di sekitarnya. Jumlah penyandang tunanetra di dunia pada tahun 2020 mencapai 285 juta. Sebanyak 14\% dari orang yang mengalami buta total dan $86 \%$ dari orang yang mengalami low vision [4]. Berdasarkan data Kementerian Kesehatan RI tahun 2012, di Indonesia tercatat sebanyak 1,5\% dari penduduk Indonesia adalah penyandang tunanetra. Banyak penelitian yang membuat alat bantu untuk tunanetra dengan menggunakan teknologi yang canggih tetapi masih kurangnya alat untuk membantu penyandang tunanetra melawan penyebaran virus covid-19 [14].

Pada tahun 2016 telah dilakukan penelitian oleh Fadli Sirait dan Yoserial mengenai computer vision menggunakan raspberry pi sebagai processornya. Pada penelitian ini dilakukan pengenalan citra wajah dengan menggunakan Haar Cascade Classifier yang diimplementasikan pada library OpenCV, sedangkan metode pengenalan pola wajah menggunakan metode PCA (Principal Component Analysist) dan LDA (Linear Discrimant Analysist). Kekurangan dari penelitian ini adalah hanya mendeteksi kondisi wajah saja, masih belum bisa mendeteksi wajah dengan menggunakan masker [2]. Referensi yang dapat diambil adalah penggunaan raspberry pi untuk pendeteksian dan pengenalan wajah menggunakan camera vision.

Penelitian lain yang dilakukan oleh Miang Jiang dkk. pada tahun 2020 dengan judul "RetinaMask A Face Mask Detector". Pada penelitian membandingkan efektivitas metode yang digunakan untuk deteksi masker. Hasil penelitian yang telah dilakukan adalah performa dari deteksi masker dengan menggunakan dataset yang sama membandingkan 2 metode yaitu ResNet dan MobileNet, pada metode ResNet memiliki tingkat akurasi yang lebih baik daripada MobileNet. Namun kekurangannya adalah ResNet membutuhkan sumber daya yang cukup besar terutama pada penggunaan kartu grafis dari PC untuk melakukan pelatihan terhadap data yang ada. Kekurangan dari penelitian hanya menjelaskan efektivitas metode yang digunakan dalam pengklasifikasian menggunakan metode MobileNet dan ResNet [4]. Referensi yang dapat diambil adalah penggunaan metode MobileNet sudah cukup untuk pengklasifikasian wajah dan masker.

Selanjutnya penelitian yang telah dilakukan oleh Wahyudi Setyo Pambudi dkk membuat sistem deteksi dan estimasi jarak menggunakan teknologi computer vision dengan menggunakan segmentasi pengolahan citra warna model HSV. Dalam proses pendeteksian objek, pada penelitian ini menggunakan segmentasi warna HSV. Pada tahap segmentasi model HSV, terjadi proses konversi dari RGB ke HSV, thresholding, estimasi tinggi dan luas dari hasil thresholding dan memberikan tanda pada objek. Dengan memberikan nilai thresholding pada model segmentasi HSV didapatkan informasi visual untuk menentukan objek. Kekurangan dari penelitian ini hanya menjelaskan adalah perhitungan estimasi jarak suatu benda, menggunakan metode perhitungan warna HSV pada citra, belum bisa menghitung jarak dengan perhitungan menggunakan citra yang didapatkan [7]. Referensi yang dapat diambil adalah konsep perhitungan estimasi jarak menggunakan citra yang didapatkan.

Pada penelitian yang telah dilakukan oleh Aldian Jefiza mengenai sistem pendeteksi jatuh menggunakan sensor gyroscope dan accelerometer menggunakan backpropagation untuk mengenali Gerakan jatuh ke depan, jatuh ke samping jatuh ke belakang, duduk, tidur, jongkok, naik tangga, turun tangga dan gerakan shalat. Hasil penelitian yang telah dilakukan didapatkan akurasi rata-rata sebesar 97,12\% [1].

Penelitian lain dilakukan oleh Ignatius Agus Supriyono dkk merancang alat untuk membantu tunanetra dan manula untuk dapat mengetahui isi buku tanpa harus membacanya dengan mengubah buku menjadi audio. Perancangan alat ini membutuhkan Raspberry Pi sebagai pemutar audiobook dan penyimpanan file audiobook serta dilengkapi RFID reader RDM6300 sebagai pemilihan buku yang sederhana menggunakan earphone sebagai luaran sistem. Prinsip kerja audiobook player ini dengan menjalankan program pada raspberry pi maka sistem akan siap digunakan dengan menempelkan RFID ke modul RDM6300 maka audio akan terputar. Kekurangan dari penelitian adalah pemutaran audio tidak dapat otomatis, harus dengan menggunakan RFID agar dapat memutar audio [11]. Referensi yang dapat diambil adalah konsep pemutaran audio agar informasi dapat diterima oleh penyandang tunanetra [6]. 
Pada tahun 2018 telah dilakukan penelitian oleh Tata Supriyadi merancang sebuah alat berupa tongkat pintar sebagai alat bantu mengawasi keberadaan penyandang tunanetra melalui smartphone. Tongkat pintar dirancang untuk membantu mengawasi keberadaan penyandang tunanetra dengan menggunakan sensor GPS yang terintegrasi dengan mikrokontroler untuk mengolah data lokasi yang berupa longitude dan latitude [13]. Data lokasi yang didapatkan pada web server selanjutnya akan ditampilkan pada Google Maps dengan menggunakan Google Maps API. Hasil pengujian tongkat pintar ini mampu menampilkan keberadaan penyandang tunanetra melalui aplikasi smartphone.

Berdasarkan penelitian yang telah ada maka pada penelitian ini bertujuan untuk merancang alat bantu deteksi masker dan estimasi jarak untuk penyandang tunanetra menggunakan metode CNN dengan arsitektur MobileNet V2. Alat ini dilengkapi sensor MLX90614 sebagai sensor suhu, MPU6050 sebagai sensor gyroscope untuk mengenali gerakan jatuh dan sensor GPS Ublox Neo 6M sebagai sensor lokasi. Sistem pengawasan terhadap penyandang tunanetra terintegrasi dengan internet, sehingga pengasuh dapat mengetahui kondisi, suhu badan dan lokasi keberadaan penyandang tunanetra melalui aplikasi smartphone.

\section{METODE PENELITIAN}

Metode penelitian yang dilakukan untuk membangun Alat Bantu Deteksi Masker dan Pengawasan Sebagai Pencegahan Virus Covid-19 Pada New Normal Bagi Penyandang Tunanetra ini meliputi merumuskan masalah, merumuskan tujuan penelitian, studi literatur, analisis kebutuhan sistem, desain dan perancangan sistem dan pengujian alat.

\section{a. Merumuskan Masalah}

Pada tahapan ini dilakukan perumusan permasalahan aktivitas yang dihadapi penyandang tunanetra dan pengasuh pada saat pandemi Covid-19. Pada masa pandemi ini adalah mengubah kebiasaan masyarakat berperilaku sehat dengan menerapkan protokol kesehatan berupa menggunakan masker dan menjaga jarak untuk menekan penyebaran virus Covid-19. Berdasarkan studi lapangan yang telah dilakukan pada Panti Asuhan Tunanetra Aisyiyah Ponorogo, penyandang tunanetra kesulitan untuk mengetahui orang di sekitarnya menerapkan protokol kesehatan atau tidak. Selain itu pengasuh terkadang membutuhkan alat yang dapat untuk mengawasi lokasi serta keadaan penyandang tunanetra.

\section{b. Merumuskan Tujuan Penelitian}

Setelah mengetahui masalah yang ada, tujuan penelitian mulai dirumuskan yaitu penyandang tunanetra dapat mengetahui orang di sekitarnya menerapkan protokol kesehatan dengan memakai masker dan menjaga jaraknya. Pengasuh dapat melakukan pengawasan lokasi keberadaan, suhu dan keadaan penyandang tunanetra. Bentuk pengawasan keadaan tunanetra yang dimaksud adalah apabila terjadi sesuatu hal yang tidak diharapkan, maka sistem akan mengirimkan informasi kepada pengasuh. Kejadian yang tidak diharapkan bisa berupa permintaan bantuan tunanetra kepada pengasuh, sehingga tunanetra dapat memintabantuan melalui tombol emergency. Apabila penyandang tunanetra mengalami musibah terjatuh, maka sistem secara otomatis mengirimkan informasi kepada pengasuh melalui smartphone.

\section{c. Studi Literatur}

Studi literatur dilakukan untuk melakukan analisa dan mencari sistem yang cocok untuk diaplikasikandan dapat menyelesaikan permasalahan yang ada sehingga tujuan penelitian terpenuhi.

\section{d. Analisa Kebutuhan Sistem}

Analisa kebutuhan sistem adalah tahapan untuk mengetahui kebutuhan-kebutuhan sistem yang akan dibangun dengan memperhitungkan dan memperinci kebutuhan yang diperlukan sistem untuk dapat dibuat.Pada tahap ini dilakukan analisa terhadap data-data dan teknologi yang diperlukan meliputi :
1. Personal Computer (PC)
4. Powerbank
2. Webcam Logitech $\mathrm{C} 270$
5. Earphone

3. Raspberry Pi $3 B+$

Selain perangkat yang telah disebutkan, dalam sistem dibutuhkan library pada python yangdibutuhkan di antaranya sebagai berikut :
1. Tensorflow $>=1.15 .2$
2. Keras
$==2.3 .1$
3. Imutils
$==0.5 .3$
4. Numpy $==1.18 .2$
5. Opencv-python $==4.2 .0$
6. Matplotlib ==3.2.1

7. Scipy ==1.4.1 
Dengan tersedianya kebutuhan sistem, maka akan mempermudah dalam proses perancangan sistem yang akan dibuat.

\section{e. Desain \& Perancangan Sistem}

Setelah diketahui kebutuhan sistem, dasar-dasar ilmu dan teknologi yang akan digunakan, maka tahapan yang selanjutnya adalah dengan melakukan perancangan dan desain sistem yang akan dikembangkan, meliputi:

\section{Perancangan Sistem}

Diagram sistem yang akan dibuat pada "Alat Bantu Deteksi Masker Sebagai Pencegahan Virus Covid-19 Pada New Normal Bagi Penyandang Tunanetra" dapat dilihat pada Gambar 1.

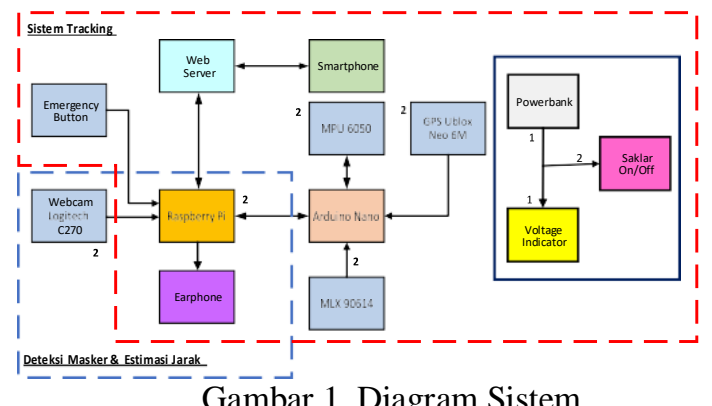

Berdasarkan diagram blok sistem pada Gambar 1 dapat diketahui dengan menggunakan perangkat Webcam dan Raspberry $P i$ kemudian dapat menghasilkan sistem deteksi masker dan estimasi jarak. Webcam berfungsi sebagai sensor untuk dapat menangkap citra kemudian diolah dengan Raspberry Pi. Citra yang sudah diolah melalui Raspberry $P i$ akan memberikan klasifikasi dari hasil citra yang didapatkan yaitu memakai masker atau tidak dan juga perhitungan estimasi jarak orang yang berada di depannya dengan pengguna. Pada sistem pengawasan menggunakan perangkat Arduino nano sebagai mikrokontroler yang bertugas mengolah data dari sensor GPS, sensor MLX 90614 dan sensor MPU 6050 yang kemudian ditransmisikan pada Raspberry Pi agar dapat dikirim ke web server. Data sensor yang telah dikirimkan ke web server dapat diakses melalui aplikasi pada smartphone.

Dalam pengklasifikasian pengguna masker dan non masker terdapat 2 tahapan, yaitu Tahap 1 proses training data dan Tahap 2 proses pengklasifikasian deteksi wajah. Diagram blok pengklasifikasian masker dan jarak dapat dilihat pada Gambar 2.

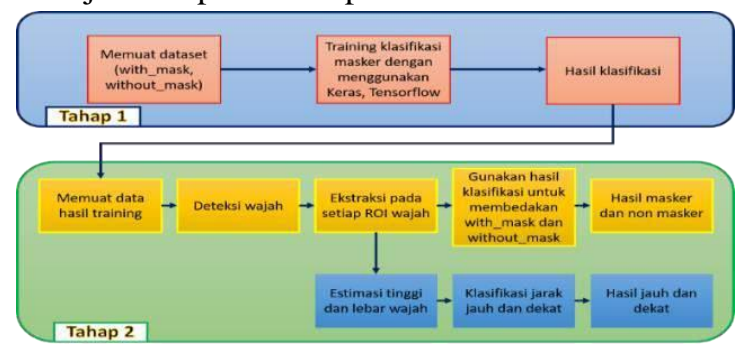

Gambar 2. Diagram Blok Pengklasifikasian Masker

Pada proses pembuatan model untuk pengklasifikasian masker dan non masker pada Gambar 2 menggunakan Keras dan Tensorflow dengan menggunakan dataset yang telah dibuat. Setelah proses pelatihan selesai, didapatkan model untuk pengklasifikasian masker dan non masker.

Pada pengklasifikasian pengguna masker dan non masker menggunakan model yang telah didapatkan. Model hasil pelatihan yang telah didapatkan akan digunakan untuk pengklasifikasian dari hasil deteksi wajah oleh kamera, selanjutnya dari hasil pendeteksian wajah akan diolah oleh komputer dan diklasifikasi pengguna masker atau non masker. Selain hasil pengklasifikasian masker dan non masker, gambar yang didapatkan dari hasil deteksi wajah dapat digunakan untuk mengklasifikasi jarak dengan estimasi tinggi dan lebar wajah. Sehingga luaran yang didapatkan adalah pengklasifikasian pengguna masker/non masker dan jarak jauh/dekat.

Perangkat yang sudah terhubung dengan internet akan melakukan proses pengiriman data lokasi terakhir, suhu dan keadaan penyandang tunanetra yang dapat digunakan pengasuh untuk mengawasi penyandang tunanetra. Diagram alir pengiriman data sistem pengawasan penyandang tunanetra dapat dilihat pada Gambar 3. 


\section{Perancangan Mekanik}

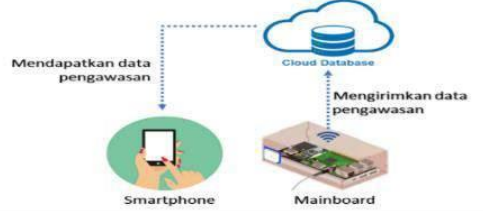

Gambar 3. Diagram Alir Pengiriman Data

Dalam perancangan “Alat Bantu Deteksi Masker Sebagai Pencegahan Virus Covid-19 Pada New Normal Bagi Penyandang Tunanetra" dengan menggunakan media sabuk dada seperti pada Gambar 3. Pemilihan sabuk dada sebagai media penempatan alat bertujuan agar mengurangi noise pembacaan citra menggunakan kamera dan pengguna dapat beraktivitas tanpa merasa terganggu. Alat ini dibagi menjadi 2 bagian, yaitu box kamera dan box mainboard. Kedua bagian tersebut menggunakan sabuk dada sebagai media peletakan alat, dengan box kamera diletakkan bagian depan dada dan mainboard pada punggung pengguna. Adapun perancangan desain alat oleh pengguna seperti Gambar 3.

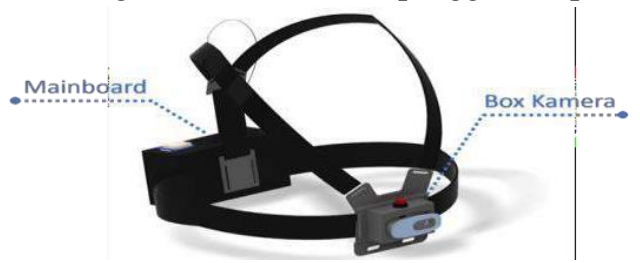

Gambar 3. Desain Perancangan Mekanik

Pada gambar 4 merupakan rancangan desain pada box kamera, box mainboard, sensor kamera. Penyandang tunanetra akan mengetahui hasil klasifikasi yang telah dilakukan melalui earphone.

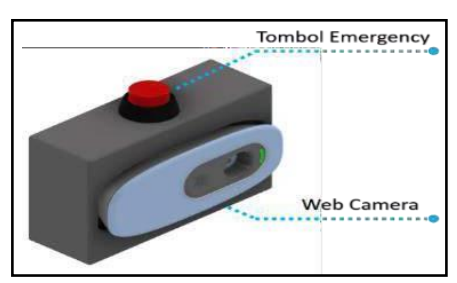

(a) Box Kamera

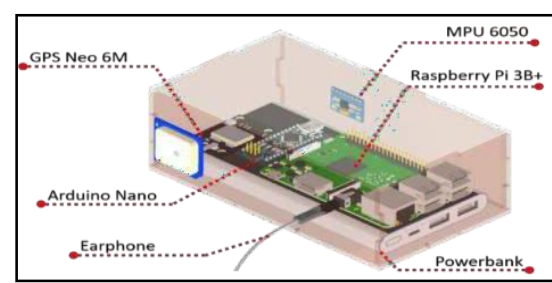

(b) Box Mainboard

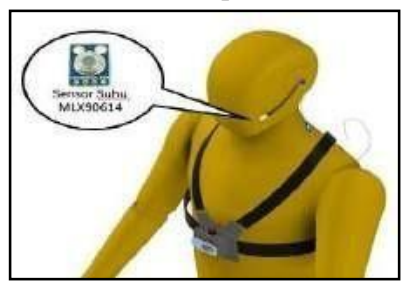

(c) Sensor Kamera

Gambar 4. Perancangan Desain Box Kamera, Box Mainboard dan Sensor Suhu

Skema rangkaian elektronika pada keseluruhan yang terhubung dengan mainboard dapat dilihat pada Gambar 5.

\section{f. Pengujian Alat}

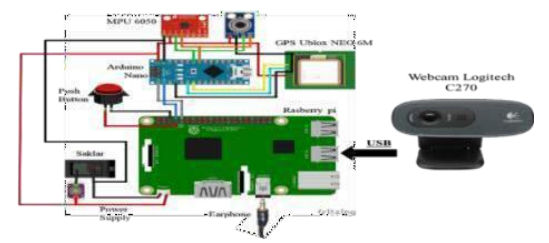

Gambar 5. Skema Rangkaian Elektronika

Pada tahap ini dilakukan pengujian alat dengan metode black box, dimana semua fungsi akan diuji per bagian untuk memastikan semua sistem dapat bekerja dengan baik mulai dari sistem deteksi masker, estimasi jarak dan pengawasan penyandang tunanetra sampai data penyandang tunanetra dapat dilihat melalui aplikasi smartphone pengasuh. 


\section{ANALISA DAN HASIL}

Penelitian "Alat Bantu Deteksi Masker Sebagai Pencegahan Virus Covid-19 Pada New Normal Bagi Penyandang Tunanetra" menggunakan dataset yang telah dikumpulkan melalui pencarian gambar di google dan pengambilan citra sendiri dari orang terdekat. Dataset terdiri dari 2 kelas yaitu citra Dalam menggunakan masker sebanyak 2052 gambar, dan citra tanpa menggunakan masker sebanyak 2046 gambar. Kumpulan dataset tersebut dapat dilihat pada Gambar 6.

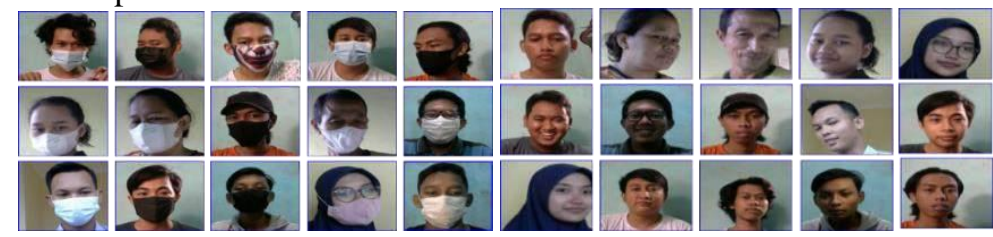

Gambar 6. Kumpulan Dataset Masker dan Non Masker

Setelah berhasil mengumpulkan dataset orang dengan menggunakan masker dan non masker dengan jumlah total 4098 foto, menggunakan masker 2052 foto dan non masker 2046 foto. Dataset tersebut dilakukan pelatihan dengan Deep Learning menggunakan algoritma MobileNet V2 yang menggunakan versi mutakhir dari MobileNet dalam arsitektur CNN (Convolution Neural Network) [5]. Adapun parameter yang digunakan, yaitu learning rate 0.0001 , batch size 32 dan jumlah epoch 20. Fungsi aktivasi yang digunakan pada layer konvolusi adalah Rectified Linier Unit (ReLU), optimizer menggunakan Adam Optimizer, dan loss function menggunakan binary_crossentropy. Pada penelitian ini juga menggunakan dropout untung menghindari overfitting [12]. Setiap model yang dilatih dengan menggunakan $80 \%$ data dan $20 \%$ untuk validasi pada masing-masing kelas. Model yang diimplementasikan menggunakan library Keras. Proses training data membutuhkan waktu yang cukup lama, dalam proses training data tergantung dari spesifikasi perangkat yang digunakan. Tampilan proses training data ditunjukkan pada Gambar 7.

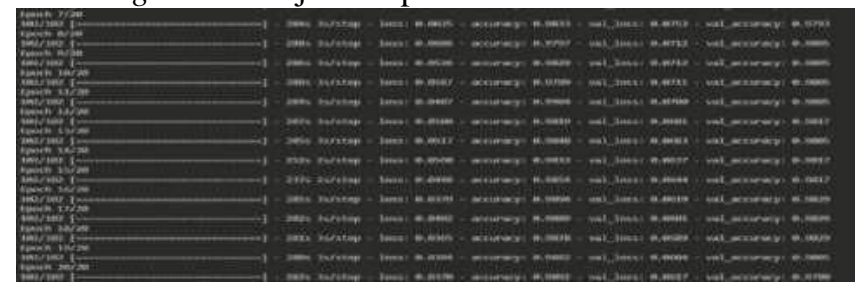

Gambar 7. Proses Training Data

Performa model deep learning dievaluasi menggunakan performa akurasi, presisi, recall, F1-score dan waktu komputasi. Performa model deep learning yang telah dilakukan dapat dilihat pada Tabel 1.

Tabel 1. Performa Model Deep Learning

\begin{tabular}{cccc}
\hline & precision & recall & fl-score \\
\hline with_mask & 0.98 & 0.98 & 0.98 \\
without_mask & 0.98 & 0.98 & 0.98 \\
accuracy & & & 0.98 \\
macro avg & 0.98 & 0.98 & 0.98 \\
Weight avg & 0.98 & 0.98 & 0.98 \\
\hline
\end{tabular}

Grafik hasil proses training dataset deteksi masker ditunjukkan pada Gambar 8. Pada Gambar 10 dapat dilihat bahwa model mencapai konvergen pada epoch 20, selain itu didapatkan nilai yang cukup stabil dan tidak terdapat noise sehingga model bisa generalisasi ke dataset sesungguhnya. Dari hasil training yang telah dilakukan, model dapat ditanamkan pada Raspberry Pi untuk implementasi deteksi masker dan estimasi jarak.

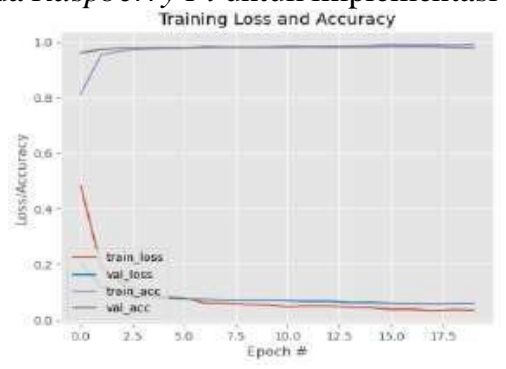

Gambar 8. Grafik Training Model 
Perhitungan estimasi jarak dilakukan dengan cara mengukur nilai ukuran dari bounding box yang mendeteksi wajah. Citra hasil deteksi wajah akan diberikan sebuah kotak sehingga didapatkan titik startX, endX, start $Y$ dan end $Y$ dapat dilihat pada Gambar 9.

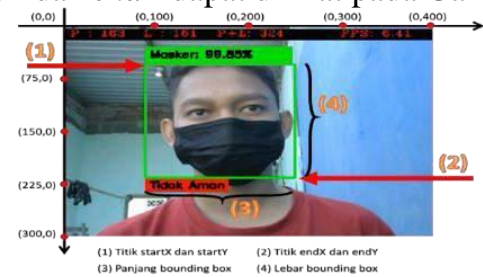

Gambar 9. Pengukuran Estimasi Jarak

Untuk dapat membuat estimasi jarak berdasarkan objek yang dideteksi dapat menggunakan perhitungan matematis dengan persamaan sebagai berikut :

$$
\text { Hasil estimasi }=(\text { end } X-\operatorname{start} X)+(\text { end } Y-\operatorname{start} Y)
$$

Pengujian deteksi masker dan estimasi jarak dilakukan dengan mengambil data dari beberapa jenis masker yang dipakai baik pria maupun wanita sehingga dapat diketahui apakah sistem deteksi masker berhasilatau tidak. Pada pengujian deteksi masker ini dengan menggunakan Raspberry Pi mendapatkan nilai FPS sebesar 0,33. Pengujian masker dilakukan dengan objek berada di depan kamera menggunakan masker dan tidak menggunakan masker dapat dilihat pada Gambar 10.

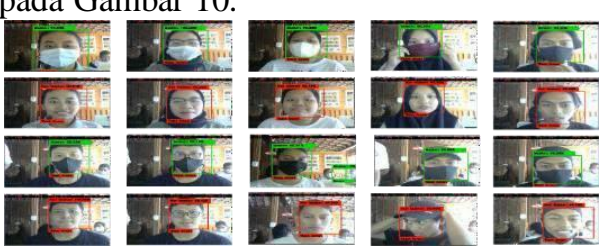

Gambar 10. Deteksi Masker dan Estimasi Jarak

Pendeteksi masker dan jarak akan memberikan informasi kepada pengguna melalui earphone dengan output yang akan diberikan oleh sistem. Output yang dihasilkan dari pengklasifikasian deteksi masker dan jarak. Pada Tabel 2 dapat dilihat output pengklasifikasian yang telah dilakukan.

Tabel 2. Output Deteksi Masker dan Estimasi Jarak

\begin{tabular}{|c|c|c|c|}
\hline No & Deteksi Masker & Deteksi Jarak & Output \\
\hline 1 & Memakai Masker & Jarak > 1 meter & Memakai Masker, Jarak Aman \\
\hline 2 & Memakai Masker & Jarak $=<1$ meter & $\begin{array}{c}\text { Memakai Masker, Jarak Tidak } \\
\text { Aman }\end{array}$ \\
\hline 3 & Tidak Memakai Masker & Jarak $>1$ meter & $\begin{array}{c}\text { Tidak Memakai Masker, Jarak } \\
\text { Aman }\end{array}$ \\
\hline 4 & Tidak Memakai Masker & Jarak $<=1$ meter & $\begin{array}{c}\text { Tidak Memakai Masker, Jarak } \\
\text { Tidak Aman }\end{array}$ \\
\hline
\end{tabular}

Implementasi deteksi masker, estimasi jarak dan sistem pengawasan penyandang tunanetra dilakukan dengan merakit alat yang telah dirancang sebelumnya. Kemudian dengan penyandang tunanetra memakai alat tersebut dibantu oleh pengasuh, pengasuh dapat melihat suhu badan, kondisi dan lokasi keberadaan penyandang tunanetra yang ditunjukkan pada Gambar 11.
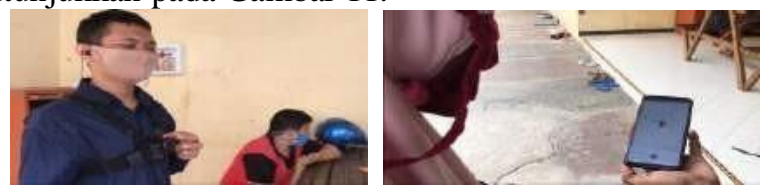

Gambar 11. Implementasi Deteksi Masker, Estimasi Jarak dan Lokasi Penyandang Tunanetra Sistem tracking penyandang tunanetra dapat mengetahui lokasi keberadaan terakhir penyandang tunanetra, pengasuh dapat memonitoring suhu badan, keadaan dan lokasi penyandang tunanetra melalui aplikasi smartphone. Pengujian notifikasi pada smartphone pengasuh dengan membuat aplikasi khusus yang akan mengirimkan notifikasi otomatis berupa teks pop-up. 
(a) Terjatuh

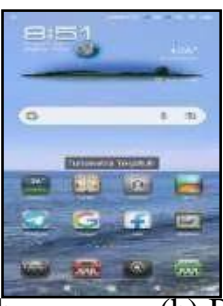

(b) Butuh Bantuan

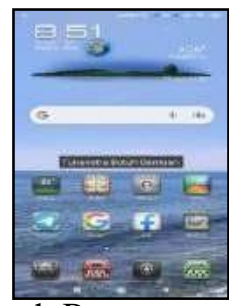

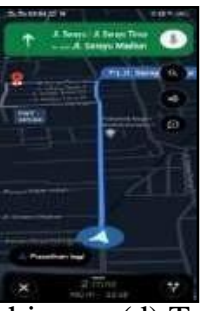

(d) Tracking

Pada saat pengasuh mendapatkan notifikasi bahwa penyandang tunanetra dalam keadaan bahaya, pengasuh dapat melakukan tracking lokasi terakhir penyandang tunanetra melalui aplikasi smartphone seperti yang ditampilkan pada Gambar 12.

\section{KESIMPULAN}

Alat Bantu Deteksi Masker penyandang tunanetra sebagai bentuk pencegahan virus Covid-19 pada New Normal dapat berjalan dengan baik, mampu mendeteksi masker dan melakukan estimasi jarak kemudian hasil klasifikasi dapat diterima oleh pengguna melalui earphone. Pengasuh dapat melakukan pengawasan suhu badan, kondisi dan lokasi terakhir penyandang tunanetra melalui aplikasi smartphone.

Kekurangan utama dari sistem ini adalah streaming video dengan menggunakan Raspberry Pi hanya memperoleh FPS sebesar 0,33 dan hanya dapat melakukan deteksi masker pada jarak kurang dari 3 meter. Saran untuk kedepannya dalam perancangan sistem deteksi masker, estimasi dan pengawasan tunanetra ini menggunakan perangkat yang lebih tinggi dari Raspberry Pi $3 B+$.

\section{REFERENSI}

[1] A. Jefiza, "Sistem Pendeteksi Jatuh Berbasis Sensor Gyroscope Dan Sensor Accelerometer,” p. 33, 2017.

[2] F. Sirait, and Yoserizal, "Pemanfaatan raspberry pi sebagai processor pada pendeteksian dan pengenalan pola wajah". Jurnal Teknologi Elektro, 7(3), 141583, 2020.

[3] I. P. Adi, H. Kusuma and M. Attamimi, "Blind People Guidance System using Stereo Camera," 2019 International Seminar on Intelligent Technology and Its Applications (ISITIA), 2019, pp. 298-303, doi: 10.1109/ISITIA.2019.8937173.

[4] Jiang, M., Fan, X., \& Yan, H. (2020). Retinamask: A face mask detector. arXiv preprint arXiv:2005.03950.

[5] M. Sandler, A. Howard, M. Zhu, A. Zhmoginov, and L. C. Chen, "MobileNetV2: Inverted Residuals and Linear Bottlenecks," Proc. IEEE Comput. Soc. Conf. Comput. Vis. Pattern Recognit., pp. 4510- 4520, 2018, doi: 10.1109/CVPR.2018.00474.

[6] Oproescu, M., Iana, G. V., Bizon, N., Novac, O. C., \& Novac, M. C. (2019, June). Software and hardware solutions for Using the keyboards by blind people. In 2019 15th International Conference onEngineering of Modern Electric Systems (EMES) (pp. 25-28). IEEE.

[7] Pambudi, Wahyu Setyo. "Deteksi Dan Estimasi Jarak Obyek Menggunakan Single Camera Dengan Model Segmentasi HSV." Seminar Nasional Teknoin 2011, 2011.

[8] P. Sutrisno, H. P. Pribadi, and R.A. Ifadah. "Peran Serta Dalam Melaksanakan Protokol Pencegahan Penyebaran Corona Virus Disease (Covid-19) Pada Masyarakat.” DedikasiMU(Journal of CommunityService) [Online], 2.3 (2020): 504-510. Web. 27 Jul. 2021

[9] R. Djalante et al., "Review and analysis of current responses to COVID-19 in Indonesia: Period of January to March 2020," Prog. Disaster Sci., Apr 2020.

[10] Septiana, T., Puspita, N., Fikih, M. A., \& Setyawan, N. (2020). "Face Mask Detection Covid-19 Using Convolutional Neural Network ( Cnn )". Seminar Nasional Teknologi Dan Rekayasa (SENTRA) 2020,27-32.

[11] Supriyono, I. A., Ramadhan, N. F. B., \& Prasetyo, M. S. B. "Perancangan Alat Audiobook Player Untuk Manula Dan Tunanetra Dengan Raspberry Pi". Innovative Creative and Information Technology, 3(1),32-41.

[12] T. P. Velavan and C. G. Meyer, "The COVID-19 epidemic,” Trop. Med. Int. Heal., vol. 25, no. 3, pp. 278-280, 2020.

[13] T. Supriyadi, "Tongkat Pintar Sebagai Alat Bantu Pemantau Keberadaan Penyandang Tunanetra Melalui Smartphone", SENTER, pp. 181-191, Jan. 2019.

[14] V. Kunta, C. Tuniki and U. Sairam, "Multi-Functional Blind Stick for Visually Impaired People," 2020 5th International Conference on Communication and Electronics Systems (ICCES), 2020, pp. 895-899, doi: 10.1109/ICCES48766.2020.9137870.

[15] World Health Organization, "Laboratory testing for 2019 novel coronavirus (2019-nCoV) in suspected human cases,” vol. 2019, no. Januari, hal. 1-7, 2020. 